International Research Journal of Management, IT \& Social Sciences
Available online at https://sloap.org/journals/index.php/irjmis/
Vol. 6 No. 4, July 2019, pages: 31 36
ISSN: 2395-7492
https://doi.org/10.21744/irjmis.v6n4.639

\title{
Effect of Intervention of Management and Audit Fee on Auditor Independence
} I Putu Agus Atmaja Negara ${ }^{\text {a }}$
I Ketut Budiartha

Article history:

Received: 27 March 2019

Accepted: 31 May 2019

Published: 7 June 2019

\section{Keywords:}

audit fee;

auditor;

independence;

intervention;

management;

\begin{abstract}
The purpose of this study was to determine the effect of management intervention and audit fees on auditor independence. This research was conducted at the Office of Public Accounting in Bali Province. The data analysis technique used is multiple linear regression analysis. The results found that Management intervention had a negative effect on Auditor Independence. This shows that the stronger the management intervention, the weaker the auditor's independence. Audit Fee has a positive effect on Auditor Independence. This shows that the higher the audit fee, the auditor's independence will also increase.
\end{abstract}

2395-7492@ Copyright 2019. The Author. This is an open-access article under the CC BY-SA license (https://creativecommons.org/licenses/by-sa/4.0/) All rights reserved.

\section{Author correspondence:}

I Putu Agus Atmaja Negara,

Faculty of Economics and Business, Udayana University, Denpasar, Indonesia

Jalan P.B. Sudirman, Dangin Puri Kelod, Denpasar, Bali 80234

Email address: agusatmajal@gmail.com

\section{Introduction}

There are many factors that influence auditor independence, one of which is management intervention. According to Harhitno (2004), management intervenes with auditors to influence the function of testing financial statements by forcing auditors to take actions that violate audit standards, including in giving opinions that are not in accordance with the client's actual circumstances. Auditors are often faced with situations that require auditors to reduce activities that reduce audit quality or are commonly called reduced audit quality (RAQ). Pressure from management has the intention that the audited report by the auditor can produce a good report so that users of financial statements feel happy. The Meilisa (2012), study shows that auditors who feel limited and in a little depressed will be disturbed and even tend to follow the management's willingness to give opinions that are not in accordance with the facts. Prabowo \& Samsudin (2010), stated that client management intervention had a positive and significant effect on auditor independence while Hakim \& Yendrawati (2016), stated that management intervention had a negative effect on auditor independence.

\footnotetext{
a Faculty of Economics and Business of Udayana University, Bali, Indonesia ${ }^{\mathrm{b}}$ Faculty of Economics and Business of Udayana University, Bali, Indonesia
} 
In addition to management interventions, audit fees are also known to affect auditor independence. Audit fees are income whose results vary because it depends on several factors in the audit assignment, such as the size of the client company, the complexity of audit services faced by the auditor, audit risk faced by the auditor and the name of the public accounting firm that performs audit services (Nugrahani \& Sabeni, 2013). The auditor will behave professionally and in accordance with the accounting code of ethics if the planned audit procedures, qualified human resources, and audit implementation programs are supported by various factors that are not escaped from the fund. Public accounting firms will tend to make better audit procedures, better quality HR, and longer audit procedures. With the consideration of audit costs, the auditor will logically act in accordance with the applicable professional ethics, and auditor performance will be better, this is what underlies that the number of audit fees will increase auditor independence.

The financial condition of a strong client can provide a large audit fee and provide good audit facilities for the auditor. The fee given by the client aims to provide enthusiasm or motivation to the auditor to carry out audit duties seriously and efficiently (Nor, 2013). El-Gammal's (2012), the study proves that multinational companies and banks in Lebanon prefer to pay large-scale audit fees on the grounds that they are more looking for auditors in public accounting firms who can produce quality audit reports and can increase the credibility of financial statements annual that can compete throughout the world. The Ika \& Wibowo (2011) and Brilliant \& Kartika (2015), studies state that the magnitude of audit fees has a positive and significant effect on auditor independence, while the research of Retty \& Kusuma (2001) states that audit fees have no effect on auditor independence.

This research was conducted to examine the effect of management intervention, and audit fees on auditor independence. The reason for choosing the auditors of public accounting firms in Bali as respondents is because previous studies on the influence of management interventions and audit fees on auditor independence focused on auditors outside of Bali, such as Jakarta and Yogyakarta, and others, but no one has focused its research on KAP auditors in Bali.

\section{Literature Review \& Hypotheses Development}

\section{The Effect of Management Interventions on the Auditor Independence}

Auditors are often faced with situations that require auditors to reduce activities that reduce audit quality or are commonly called reduced audit quality (RAQ). Based on the research of Meilisa (2012); Dewi et al., (2018); Adetunji et al., (2017), shows that auditors who feel limited and in a little depressed will be disturbed and even tend to follow the management's willingness to give opinions that are not in accordance with the facts. Symptoms like this are indicative of a decrease in audit quality and auditor independence. This can be experienced by auditors, even though large KAPs remain vulnerable to disruptions in management intervention. According to Jatmiko \& Syamsudin (2010), auditor independence fades in conflict situations. The conflict situation is increasingly tapering when the client begins to intervene in the audit process so that it will influence the auditor's opinion on historical financial statements. Prabowo \& Samsudin (2010), stated that client management intervention had a positive and significant effect on auditor independence while Hakim \& Yendrawati (2016); Sanjaya et al., (2019); Kesuma et al., (2019), stated that management intervention had a negative effect on auditor independence. Based on the description, the H1 hypothesis formulation is as follows:

H1: Management interventions have a negative effect on auditor independence.

\section{The Effect of Audit Fees on Auditor Independence}

Audit fees are income whose results vary because it depends on several factors in the audit assignment, such as the size of the client company, the complexity of audit services faced by the auditor, audit risk faced by the auditor and the name of the public accounting firm that performs audit services (Nugrahani \& Sabeni, 2013). The auditor will behave professionally and in accordance with the accounting code of ethics if the planned audit procedures, qualified human resources, and audit implementation programs are supported by various factors that are not escaped from the fund. Ika \& Wibowo (2011) and Brilliant \& Kartika (2015) research stated that the magnitude of audit fees has a positive and significant effect on auditor independence, while the research of Retty \& Kusuma (2001); Zambrano et al., (2018); Jain (2017), states that audit fees have no effect on auditor independence This is because the accountant's office the public will tend to make better audit procedures, better quality human resources, and longer audit procedures. With the consideration of audit costs, the auditor will logically act in accordance with the applicable professional 
ethics, and the auditor's performance will be better, this is what underlies that the amount of the audit fee will increase auditor independence. Based on the description, the formulation of the $\mathrm{H} 2$ hypothesis is as follows.

H2: Audit fees have a positive effect on auditor independence

\section{Materials and Methods}

This research was conducted in KAP Bali Province. The technique used by researchers in selecting samples is nonprobability sampling, namely purposive sampling. The research instrument used was a questionnaire that would be answered by auditors in KAP throughout the Province of Bali. The analysis technique used in this study is the multiple linear regression.

\section{Results and Discussions}

Testing the hypothesis in this study uses multiple regression analysis. The results of the calculations are presented in Table 1.

Table 1

SPSS Output

\begin{tabular}{llll}
\hline Variable & Standardized Beta & $\begin{array}{l}\text { Probability } \\
\text { (sig.) }\end{array}$ & Description \\
\hline Constant & 18,804 & 0,000 & Sig. \\
Management Interventions (IM) & $-0,327$ & 0,002 & Sog. \\
Fee Audit (FA) & 0,275 & 0,003 & \\
Adjusted R Square & 0,454 & & \\
F & 19,728 & & \\
Probability (p-value) & 0,000 & & \\
\hline
\end{tabular}

Primary Data, 2019

Based on the multiple linear regression equation for the Auditor Independence dependent variable that has been obtained, there is a constant value of 18.804 which means that if the auditor's independence variable is not influenced by all independent variables, then the average auditor independence is 18.804 .

Regression coefficient values on the independent variables indicate that if the independent variable is increased by a value of one unit and the other independent variables are constants or other values equal to zero, then the value of the dependent variable will be adjusted to the regression coefficient.

Regression coefficients for independent variables Management Intervention (X1) are negative, indicating a unidirectional relationship between Management Interventions and Auditor Independence (Y). The Management Intervention variable regression coefficient of $-0,327$ implies that for every one basis point increase Management Intervention will cause a decrease in Auditor Independence by 0.327 basis points.

The regression coefficient for the independent variable Audit Fee (X2) is positive, indicating the existence of a unidirectional relationship between Audit Fee and Auditor Independence (Y). Audit Fee variable regression coefficient of 0.275 means that for each one basis increase, Audit Fee points will cause an increase in Auditor Independence by 0.275 basis points.

\section{Adjusted R Square Coefficient}

Based on Table 1 the adjusted $\mathrm{R}$ square value of 0.454 indicates that $45.4 \%$ of the variation in the value of Auditor Independence can be explained by the factors of Management Intervention and Audit Fee. While the remaining 54.6\% is influenced by other factors not observed in this study.

Negara, I. P. A. A., \& Budiartha, I. K. (2019). Effect of intervention of management and audit fee on auditor independence. International Research Journal of Management, IT and Social Sciences, 6(4), 31-36. https://doi.org/10.21744/irjmis.v6n4.639 
F Test

The p-value test results show a value of 0,000 smaller than 0.05 means that the Management Intervention and Audit Fee jointly have a significant effect on Auditor Independence.

T-test

Based on Table 1, a partial analysis of each variable can be explained. The management intervention variable has a negative coefficient of $-0,327$ with a significance value of $0,002<0,05$, which means that Management Interventions have a negative influence on Auditor Independence. Hypothesis 1 in the study was accepted. Variable Audit Fee has a positive coefficient of 0.275 with a significance value of $0.003<0.05$ means that Audit Fee has a positive influence on Auditor Independence. Hypothesis 2 in the study was accepted.

\section{The Effect of Management Intervention on Auditor Independence}

Based on the results of testing the hypothesis in the previous discussion stated that hypothesis 1 is accepted. These results indicate that management intervention has a significant negative effect on auditor independence. The stronger the management intervention, the weaker the auditor's independence. This result is also reinforced by several research results as follows: The Meilisa (2012), study shows that auditors who feel limited and in a little depressed will be disturbed and even tend to follow the management's willingness to give opinions that are not in accordance with the facts. Symptoms like this are indicative of a decrease in audit quality and auditor independence. According to Jatmiko \& Syamsudin (2010), auditor independence fades in conflict situations. The conflict situation is increasingly tapering when the client begins to intervene in the audit process so that it will influence the auditor's opinion on historical financial statements. Hakim \& Yendrawati's (2016), the study states that management intervention negatively affects auditor independence. Wiwekandari (2015), states that time budget pressures and client management interventions partially negatively influence auditor independence and audit quality. This means that the higher the time budget pressure and client management intervention experienced by the auditor, the auditor's independence and the resulting auditing quality will be lower. Hakim \& Yendrawati (2016), stated that management intervention had a negative and significant effect on auditor independence. Meilisa (2016) states that management intervention has a negative and significant effect on auditor independence. Kurnia, Yuli Endah (2018), states that management intervention has a negative and significant effect on auditor independence. Prabowo \& Samsudin (2010), state that management pressure has a negative and significant effect on auditor independence. Nicholas \& Price (1976), also state that auditor independence management pressure is influenced by management pressure.

\section{The Effect of Audit Fees on Auditor Independence}

Based on the results of testing the hypothesis in the previous discussion stated that hypothesis 2 is accepted. These results indicate that the higher the audit fee, the higher the tendency of auditor independence. Audit fees are income whose results vary because it depends on several factors in the audit assignment, such as the size of the client company, the complexity of audit services faced by the auditor, audit risk faced by the auditor and the name of the public accounting firm that performs audit services (Nugrahani \& Sabeni, 2013). The auditor will behave professionally and in accordance with the accounting code of ethics if the planned audit procedures, qualified human resources, and audit implementation programs are supported by various factors that are not escaped from the fund. Brilliant \& Kartika (2015); Cahyadi (2013); John et al., (2012); Putri et al., (2012); Maryati (2012); Ika \& Wibowo (2011); and Abu Bakar \& Ahmad (2009), states that the magnitude of audit fees has a positive and significant effect on auditor independence. This is due to the fact that public accounting offices will tend to make better audit procedures, better quality human resources, and longer audit procedures. With the consideration of audit costs, the auditor will logically act in accordance with the applicable professional ethics, and the auditor's performance will be better, this is what underlies that the amount of the audit fee will increase auditor independence. 


\section{Conclusion}

Management Interventions have a negative effect on Auditor Independence. This shows that the stronger the management intervention, the weaker the auditor's independence. Audit Fee has a positive effect on Auditor Independence. This shows that the higher the audit fee, the auditor's independence will also increase.

Further research should conduct socialization or explanation to the respondent regarding the purpose and objectives of the study so that it can lead to the same perception between researchers and respondents. Future studies should add new variables besides management intervention variables, pseudorotation, and audit fees. Expanding the questionnaire distribution area not only in Bali and increasing the number of respondents so that the data obtained is more evenly distributed and better than previous research.

Conflict of interest statement and funding sources

The authors declared that they have no competing interest.

Statement of authorship

The authors have a responsibility for the conception and design of the study. The authors have approved the final article.

\section{Acknowledgments}

The authors would like to thank the Editor of IRJMIS for their valuable time, support, and advice in completing the current study.

Negara, I. P. A. A., \& Budiartha, I. K. (2019). Effect of intervention of management and audit fee on auditor independence. International Research Journal of Management, IT and Social Sciences, 6(4), 31-36. 


\section{References}

Adetunji, A., Adetunji, A., Adeleke, E., \& Madubuike, S. (2017). Deregulation: the effect of market-led approach to Nigerian universities management. International Journal of Social Sciences and Humanities, 1(1), 1-8. https://doi.org/10.29332/ijssh.v1n1.6

Bakar, N. B. A., \& Ahmad, M. (2009). Auditor independence: Malaysian accountants' perceptions. International Journal of Business and Management, 4(12), 129-141.

Cahyadi, H. (2013). Faktor-Faktor yang Mempengaruhi Independensi Akuntan Publik (Survei pada Mahasiswa Jurusan Akuntansi Universitas di Jakarta). Karya Ilmiah Dosen, 5(1), 32-44.

Dewi, I. G. A. A. P., \& Dewi, P. P. (2018). Big Five Personality, Ethical Sensitivity, and Performance of Auditors. International Research Journal of Management, IT and Social Sciences, 5(2), 195-209.

Dewi, P. P., \& Dwiyanti, K. T. (2018). Professional commitment, self-efficacy and ethical decision auditor. International Research Journal of Management, IT and Social Sciences, 5(6), 93-104. https://doi.org/10.21744/irjmis.v5n6.379

El-Gammal, W. (2012). Determinants of audit fees: Evidence from Lebanon. International Business Research, $5(11), 136$.

Hakim, A., \& Yendrawati, R. (2016). Analisis Pengaruh Intervensi Manajemen dan Rotasi Semu Auditor terhadap Independensi Auditor dengan Fee audit sebagai variabel Moderasi. Simposium Nasional Akuntansi XIX, Lampung.

Harhinto, T. (2004). Pengaruh Keahlian dan Independensi Terhadap Kualitas Audit Studi Empiris Pada KAP di Jawa Timur. Semarang. Tesis Maksi: Universitas Diponegoro.

Ika, A. \& Wibowo, R. S. (2011). Analisis Faktor-Faktor yang Mempengaruhi Independensi Penampilan Akuntan Publik. Jurnal Dinamika Akuntansi. 3(2), 90-100.

Jain, P. (2017). Effect of online education trend on quality management. International Journal of Health Sciences, 1(1), 1-5. https://doi.org/10.21744/ijhs.v1i1.16

Jatmiko, A. Determinan struktur modal pada perusahaan manufaktur yang terdaftar di bei.

John, A. O. (2014). Effect of cash management on profitability of Nigerian Manufacturing firms. International journal of marketing and technology, 4(1), 129-140.

Kesuma, I. B. G. P. W., \& Dwirandra, A. (2019). Professional commitments and pressure of obedience in mediating on the effect of time budget pressure in quality audits. International Research Journal of Engineering, IT \& Scientific Research, 5(1), 27-38. https://doi.org/10.21744/irjeis.v5n1.587

Kurnia, Y. E. (2018). Pengaruh tenure of audit dan nintervensi manajemen terhadap independensia uditor dengan High fee audit sebagai variabel pemoderasi (studi empiris pada KAP di Yogyakarta). Skripsi. Sekolah tinggi ilmu ekonomi widya wiwaha: Yogyakarta.

Mariyati, S., \& Arisudhana, D. (2017). Faktor-Faktor yang Mempengaruhi Independensi Auditor (Studi Empiris pada Kantor Akuntan Publik di Jakarta). Jurnal Akuntansi dan Keuangan, l(2).

Mariyati, S., \& Arisudhana, D. (2017). Faktor-Faktor yang Mempengaruhi Independensi Auditor (Studi Empiris pada Kantor Akuntan Publik di Jakarta). Jurnal Akuntansi dan Keuangan, 1(2).

Meilisa, H. Pengaruh management pressure dan audit time budget pressure terhadap independensi auditor (studi empiris pada kantor akuntan publik di sumatera bagian selatan) abstrak.

Nichols, D. R., \& Price, K. H. (1976). The auditor-firm conflict: an analysis using concepts of exchange theory. The Accounting Review, 51(2), 335-346.

Nor, N. M., Lau, L. C., Lee, K. T., \& Mohamed, A. R. (2013). Synthesis of activated carbon from lignocellulosic biomass and its applications in air pollution control-a review. Journal of Environmental Chemical Engineering, 1(4), 658-666. https://doi.org/10.1016/j.jece.2013.09.017

Novianty, R., \& Kusuma, I. W. (2001). Analisis faktor-faktor yang mempengaruhi independensi penampilan Akuntan Publik. Jurnal Akuntansi dan auditing Indonesia, 5(1), 1-16.

Nugrahani, N. R., \& Sabeni, A. (2013). Faktor-Faktor yang mempengaruhi penetapan fee audit eksternal pada perusahaan yang terdaftar di BEI (Doctoral dissertation, Fakultas Ekonomika dan Bisnis).

Prabowo, T. J. W., \& Samsudin, B. (2010). Pengaruh Tekanan Manajemen Klien dan Audit Time Budget Pressure terhadap Independensi Auditor. MAKSI, 10(1).

Putri, K., \& Silalahi, S. P. (2014). Analisis faktor-faktor yang mempengaruhi independensi akuntan publik dalam pelaksanaan audit (study survey pada kantor akuntan publik di pekanbaru dan batam). Jurnal Online Mahasiswa (JOM) Bidang Ilmu Ekonomi, 1(1), 1-16.

Sanjaya Adi Putra, G., \& Dwirandra, A. A. N. B. (2019). The effect of auditor experience, type of personality and fraud auditing training on auditors ability in fraud detecting with professional skepticism as a mediation variable. International Research Journal of Management, IT and Social Sciences, 6(2), 31-43. https://doi.org/10.21744/irjmis.v6n2.604

Wiwekandari, N. M. (2015). Pegaruh Tekanan Anggaran Waktu dan Intervensi Manajemen Klien Terhadap Independensi Auditor Serta Impilkasinya pada Kualitas Audit. Jurnal Ekonomi dan Bisnis.

Zambrano, M. L. V., Barreto, M. D. L. A. C., \& Chica, T. K. M. (2018). Intervention of social work in political participation of women in forming process of neighborhood councils of canton Portoviejo. International Journal of Social Sciences and Humanities, 2(1), 134-146. https://doi.org/10.29332/ijssh.v2n1.104 